\title{
Implementing the Triple Helix Model: Means-Ends Decoupling at the State Level?
}

\author{
Myroslava Hladchenko $^{1,2}$ (D) $\cdot$ Romulo Pinheiro $^{3}$
}

\begin{abstract}
The Triple Helix is a global model originating in developed economies but less developed countries have also made attempts to implement it into their national contexts. Meanwhile, the national context can be characterised by meansends decoupling at the state level which implies that policies and practices of the state are disconnected from its core goal of creating public welfare. It refers to the oligarchic economies in which the state is captured by exploitative, rent-seeking oligarchies in business and politics. Ukraine is an example of such a country. Thus, the research question is: how did means-ends decoupling at the state level affect the implementation of the Triple Helix model in Ukraine? To answer this question, we employed both rational choice institutionalism and sociological institutionalism. The data emanate from interviews with the senior managers of four universities and science parks established within them. The findings reveal that means-ends decoupling at the state level, caused by the rent-seeking behaviour of business and political oligarchies, led to the implementation of the Triple Helix model in Ukraine also reflecting a case of means-ends decoupling. The greater the institutional complexity experienced by the science park and the more the senior managers of the university and the science park maintain a logic of confidence in practices that deviate from the Triple Helix model, the greater rent-seeking and means-ends decoupling at the organisational level. Both rent-seeking and means-ends
\end{abstract}

Myroslava Hladchenko

hladchenkom@gmail.com; m.hladchenko@utwente.nl

Romulo Pinheiro

romulo.m.pinheiro@uia.no

1 Center for Higher Education Policy Studies, University of Twente, Enschede, The Netherlands

2 Faculty of Humanities and Pedagogy, National University of Life and Environmental Sciences of Ukraine, Kyiv, Ukraine

3 Department of Political Sciences and Management, University of Agder, Kristiansand, Norway 
decoupling were found to not only hinder economic growth but also result in a diversion of human intellectual capital.

Keywords Triple Helix · Science parks · Means-ends decoupling ·

Rent-seeking · Sociological institutionalism · Institutional logics ·

Ukraine

\section{Introduction}

During the last decades, the development of the knowledge economy in Western societies has significantly changed both the roles played by universities and the relationship between the university, industry and government, resulting in the emergence of the Triple Helix (Etzkowitz and Leydesdorff 2000) as one of the global models of world society (Meyer 2010). The main idea behind the Triple Helix lies in the expansion of the role of knowledge in social development more broadly and of the university in the economy more specifically (Etzkowitz 2002). The university is expected to extend its traditional missions of knowledge transmission (teaching) and production (research) to include economic and social development (Pinheiro et al. 2015; Benneworth et al. 2015; Etzkowitz and Leydesdorff 1998), shifting from "an individual to organisational focus in each mission" (Etzkowitz 2002: 7). Moreover, public policies, and thus the institutional logic of the state, must be "an outcome of the interactions among the Triple Helix agencies" (Etzkowitz 2003: 295). Similar to other global models of world society, the Triple Helix originates and has been applied in the context of developed or mature economies, but less developed countries have also made attempts to implement this global model into their specific national contexts. Meanwhile, the specific national context as an institutional environment can be characterised by a high degree of institutional complexity caused by means-ends decoupling at the state level (Hladchenko and Westerheijden 2018; Hladchenko et al. 2018). Meansends decoupling (Bromley and Powell 2012) at the state level implies that policies and practices of the state are disconnected from its core goal of creating public welfare. Such means-ends decoupling occurs, for instance, in oligarchic economies, where the state is captured by exploitative, rent-seeking oligarchies in business and politics (Guriev and Sonin 2009). This bleak picture describes numerous postcommunist countries (Hellman 1998), one of which is Ukraine (Yurchenko 2018; Åslund 2000, 2001).

Thus, the research question addressed in this paper is as follows: How did meansends decoupling at the state level affect the implementation of the Triple Helix model in Ukraine? To answer our research question, we employ both sociological institutionalism and rational choice institutionalism. The data emanate from personal interviews with the senior managers of four universities and science parks established within them who were directly involved with the pursuit of public policy geared towards promoting the implementation of the Triple Helix in Ukraine. The paper is organised as follows. In the next section, we sketch out the general underpinnings of our theoretical framework. We then present the backdrop for the 
case and its methodological considerations, followed by a presentation of the empirical data and key findings for each of the case universities. The paper concludes by reflecting on the key findings in light of the extant literature and by providing recommendations for future policies.

\section{Theoretical Framework}

\section{Sociological Institutionalism and World Society}

New institutionalism is not a "unified body of thought" (Hall and Taylor 1996: 936) as it comprises several different analytical approaches among which are sociological institutionalism and rational choice institutionalism. The theoretical integration of these two analytical approaches allows exploring institutional change from a variety of perspectives (Koning 2016). Rational choice institutionalism is inspired by such concepts as property rights and rent-seeking (Hall and Taylor 1996), with its proponents viewing institutions as coordinating mechanisms that sustain equilibria (Mahoney and Thelen 2010), while actors are considered to be driven by selfinterests and wish to maximise utility in a strategic manner (Hall and Taylor 1996). The powerful actors can convert pre-existing institutions or externally copied institutional innovations into the object of rent-seeking. Rent-seeking behaviour implies "a return in excess of a resource owner's opportunity cost" (Tollison 1982: 575) and it can take illegal forms as rational actors often reconfigure institutions or inefficiently allocate resources to their own benefit (Krueger 1974). In various postcommunist countries rent-seeking practices have resulted in the emergence of business, political, and bureaucratic oligarchies and the obliteration of general societal wealth (Hellman1998; Wittkowsky 1999).

Sociological institutionalism is grounded in the cultural perspective with institutions referring to symbolic systems and cognitive scripts (Hall and Taylor 1996). Following the premises of sociological institutionalism, world society theory (Meyer 2010) focuses on the existence of global cultural models that function as actorhood models for states, organisations and individuals. Since the global models involve cultural or meaning systems, they are supposed to influence actors' agency, identity and activity. Despite viewing actors as culturally embedded, the global models imply agentic and purposive actorhood (Meyer 2010). Meanwhile, Meyer and Jepperson (2000) point out the variations in the social construction of agentic actorhood depending on the relationship between the state as authority and organisations and individuals (and civil society) as a social agent.

The embeddedness of states into world culture promotes the diffusion of global cultural models (Meyer et al. 1997). By adopting world models that are seen as legitimate and appropriate, states and other constructed actors are capable of drawing external and internal support or legitimacy "that rest[s] on claims to universal world applicability" (Meyer et al. 1997: 148). The national context in which global models are implemented can be viewed as a societal field that comprises organisational fields and that is guided by the institutional logics of the societal institutions such as state or market (Zietsma et al. 2016). Institutional logics 
are "socially constructed, historical patterns of material practices, assumptions, values, beliefs, and rules by which individuals ... provide meaning to their socially constructed reality" (Thornton and Ocasio 1999: 804; see also Thornton and Ocasio 2008; Thornton et al. 2012). The means and ends of organisations and individuals are enabled and constrained by prevailing institutional logics (Thornton and Ocasio 2008). Organisations, and the actors composing them, can also initiate change in the prevailing institutional logics, in which case they are called "institutional entrepreneurs" (Thornton and Ocasio 2008). Moreover, organisations often confront incompatible prescriptions emanating from a single or multiple institutional logics, thus experiencing institutional complexity (Greenwood et al. 2011; Meyer and Höllerer 2016).

The implementation of global models in a new national context requires adjustment of societal institutions in order to accommodate these new models. In those cases where no local adjustments are made, the enactment of global models results in decoupling at the state level (Meyer 2010). Bromley and Powell (2012) distinguish between policy-practice and means-ends decoupling. The former refers to a gap between policy and practice, the classical object of implementation studies. The latter refers to a gap between practices and outcomes (Bromley and Powell 2012), that is, policies are executed according to plan, yet intended outcomes are not achieved. It occurs because the implemented practices are compartmentalised from the core goals of the actor in question, e.g., state, organisation, individual (Bromley and Powell 2012). Thus, means-ends decoupling at the state level implies that policies and practices of the state do not contribute to its main goal of creating public welfare. Means-ends decoupling also involves a "goal drift or goal displacement" when means become ends in themselves (Grodal and O'Mahony 2015: 10). Consequently, means-ends decoupling entails an "efficiency gap" (Dick 2015) and the diversion of critical resources (Bromley and Powell 2012). Meansends decoupling is difficult to sustain unless the (individual) actors maintain confidence in the policy or practice (Dick 2015; Bromley and Powell 2012). Grodal and O'Mahony (2015) view means-ends decoupling at the field level as a cause of institutional complexity for an organisation. Meanwhile, institutional complexity promotes organisations in applying means-ends decoupling to attain legitimacy (Bromley and Powell 2012). Leaders and managers play a crucial role in organisational strategic responses to institutional prescriptions (Gioia et al. 2013), amongst other aspects, by attempting to address contradictory institutional logics in ways that minimise the disruption of internal activities (Berg and Pinheiro 2016).

\section{The Triple Helix as a Global Model}

Knowledge production and diffusion are widely viewed as the engines of economic and social progress in Western societies (European Commission 1997). The advent of the so-called "knowledge economy" has put a premium on the interplay between science and society/economy in the context of technology transfer and other collaborative arrangements to foster global competitiveness. As a result, conceptualisations such as the Triple Helix model (Etzkowitz and Leydesdorff 2000) have become rather prevalent across policy and academic circles alike. Heuristically, the 
Triple Helix prescribes corresponding institutional logics both at the societal field level and at the level of the organisational fields of higher education and science, on the one hand, and industry/business, on the other (Cai 2014). The core trigger for the implementation of the Triple Helix lies in the institutional logic of the state, which involves "shared beliefs on knowledge as a key to economic growth" (Cai 2014: 4). Cai (2014) argues that the dominant institutional logics in non-Western societies, which tend to be contrary to the "ideal" institutional logics of Western societies, can hinder the implementation of the Triple Helix model. Meanwhile, Etzkowitz and Leydesdorff (2000) distinguish three types of the Triple Helix model. Under the static model, the state encompasses academia and industry and directs relations between them, as found in the former Soviet Union when state-owned industries were predominant. In the case of the laissez-faire model, characterised by a limited state intervention in the economy (as is the case in the USA), the three institutional spheres are separated. In contrast to the two previous models, an ideal model of Triple Helix presupposes the existence of overlapping institutional spheres in the form of tri-lateral networks and hybrid configurations (Fig. 1).

The implementation of the ideal or overlapping Triple Helix model requires the loosening of top-down control and the creation of a civil society, thus opening the way to bottom-up innovations (Saad et al. 2008; see also Marcovich and Shinn 2011). Triple Helix implies the internal transformation of the state, industry and university. The state is expected to develop support mechanisms and provide public venture capital (Etzkowitz et al. 2001). The EU's Framework Programmes is an example of a direct initiative of the governments involved, which is aimed at moving the institutional spheres closer to one another (Etzkowitz 2003). Contracts, research projects and/or subsidies to foster innovations are among the key factors that facilitate knowledge transfer from academia to the wider world (Löfsten and Lindelöf 2002). The state is expected to be rather active at the regional and local levels insofar as developing and implementing policies and mechanisms for promoting industrial growth (Etzkowitz 2003). Industry is considered to undergo a transformation, moving away from the hierarchical model of large companies towards start-ups and academic spin-offs (Etzkowitz 2003).

In addition to state initiatives, university policies are crucial for the successful implementation of the Triple Helix (Caldera and Debande 2010; see also Geuna and Muscio 2009). The university is supposed to play a greater role in society as an entrepreneur. Yet, the overall performance of a given university in knowledge transfer depends on a multiplicity of internal characteristics (Caldera and Debande 2010), such as research excellence and a portfolio of disciplines (e.g., STEM fields) that produce knowledge which is considered attractive for industries, e.g., the biomedical and engineering faculties in the case of STEM (Lach and Schankerman 2008; Powell and Owen-Smith 2002).

As the Triple Helix model contends with the overlapping of institutional spheres, it results in the establishment of a knowledge infrastructure and organisational mechanisms fostering the rise of new social arenas for collaboration, like science parks (Etzkowitz 2003). Science parks originated in the USA in the 1950s, with the first being established in the vicinity of Stanford University. For many European countries, it was not until the 1980s and 1990s that a significant number of science 

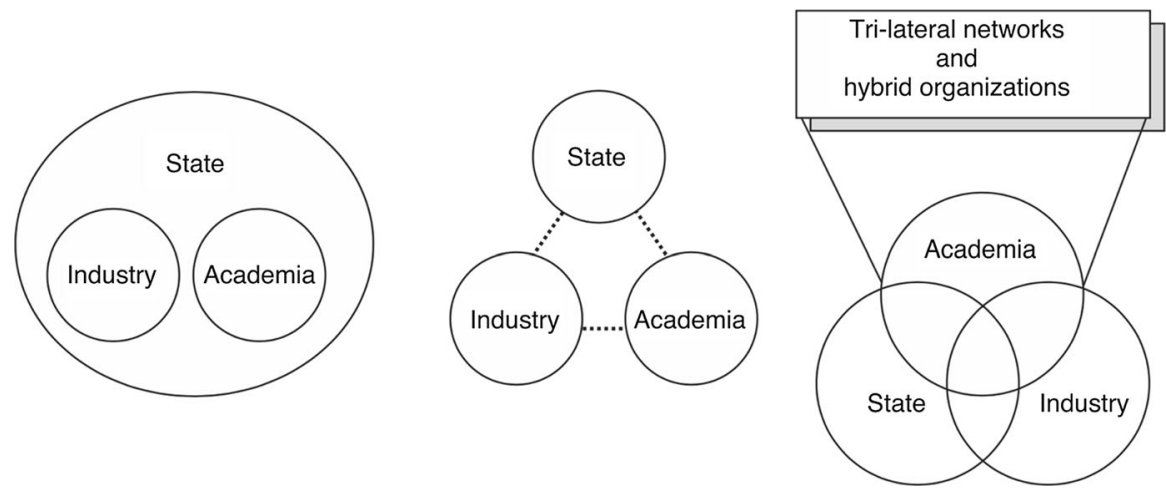

Fig. 1 From static and laissez-faire to Triple Helix (Etzkowitz 2003)

parks were established (Quintas et al. 1992), with the Nordic countries leading the way (Lester and Sotarauta 2007). Science parks diminish the problem of limited appropriability of research results as R\&D cooperation among firms within the science park decreases the costs for each individual firm as more results become widely available (Mowery and Rosenberg 1989).

\section{Methodology}

The research adopts a qualitative case study design (Yin 2009). On the policy front, the case is Ukraine, whereas four case universities and their respective science parks were chosen to investigate variations in the implementation and effects of the policy frameworks (comparative approach). As far as data collection goes, field work was conducted in the following way: the initial phase (2014-2016 period) focused on an overview of the state reforms affecting the implementation of the Triple Helix in Ukraine. During this stage of the research, official documents and publications from governmental agencies and universities were explored as the main sources of information. Semi-structured interviews $(\mathrm{N}=6)$ were also conducted with the rectors and vice-rectors of the case universities involved with the implementation of the public policy geared towards promoting the enactment of the Triple Helix. This phase led to the selection of science parks at four public Ukrainian universities. The basis for selection was twofold. Firstly, as the disciplinary profile influences the performance of the university in knowledge transfer (Pinheiro, Benneworth, and Jones 2012), we selected the science parks located in/around universities with different disciplinary profiles: Technical University, Classical University, University of Economics and University of Life Sciences. ${ }^{1}$ Secondly, Meyer and Rowan (1977) denote that while early adopters of organisational innovations are commonly driven by the desire to improve performance, late adopters mainly aim to secure public legitimacy. Thus, one case (Technical University) is the initiator of the diffusion of the Triple Helix model in the Ukrainian context, while the other cases

\footnotetext{
1 These names are chosen to preserve anonymity.
} 
are late adopters. The selected science parks were established in 2006, 2011 ${ }^{2}$ and 2015, consecutively. During 2016, semi-structured interviews were conducted with the directors $(\mathrm{N}=4)$ of the above-mentioned science parks. As the directors of the science parks were appointed by the rectors, the scope for "managerial actorhood" of the former is rather limited as they are primarily implementers of the vision set out by the rectors and/or are obliged to receive approval for their strategies from the senior managers of the university.

\section{Backdrop to the Case: Means-Ends Decoupling at the State Level in Ukraine}

Between 1919 and 1991, Ukraine was a part of the Soviet Union what implied colonial dependency on the Kremlin (Oleksiyenko 2016). During this period, the country hosted the foremost leaders of world science due to heavy involvement in military programmes (Yegorov 2009). Despite the fact that Ukraine managed to develop a rather sophisticated research infrastructure, it nonetheless lacked adequate mechanisms for research commercialisation. Over time, as the centrally planned system failed to react to the new economic and technological challenges, and as resources were distributed inefficiently, the country started to lose its leading position in the fields of electronics and biotechnology. That being said, scientific fields such as mathematics, physics and new materials remained rather strong until the beginning of the 1990s. However, neither the research institutes of the academy of sciences nor universities formed the core of the R\&D under the Soviets. Instead, this role was undertaken by the branch institutes and design bureaux directly subordinated to ministries (Yegorov 2009).

Following the fall of the Soviet Union, Ukraine was established as an independent state in 1991, which also involved the transition to a market economy. However, state policies aimed at lustration, de-Sovietisation and decommunisation were not adopted and civil society remained underdeveloped. Under such conditions, the dominance of the old Soviet elite in governmental institutions (Egorov 1996; Oleksiyenko 2016) and the concentration of resources within the state, set the stage for extraordinary rent-seeking (Åslund 2000). In 1993-94 the actors from the Soviet shadow economy joined the government to maximise their income. The rent-seeking of the ruling elite resulted in the inconsistent implementation of privatisation and in the emergence of a post-Soviet oligarchy consisting of the old Soviet political elite and actors from the Soviet shadow economy (Yurchenko 2018; Åslund 2000, 2001). As oligarchs dominated both the economy and politics, the state agencies were employed for the exploitative rent-seeking e.g., preservation of sectoral monopolies and economic subsidies (Åslund 2000, 2001). Conditions beneficial to rent-seeking behaviour were maintained through partial reforms and the blocking of radical reforms by business and political elites (Hellman 1998). These processes resulted in the emergence of a regime characterised as a "neoliberal kleptocracy", which implies that "typical neoliberal

\footnotetext{
${ }^{2}$ In 2011 the science parks were established in Classical University and University of Economics.
} 
features are exacerbated by omnipresent corruption and institutionalised state asset embezzlement" (Yurchenko 2018: 4). Drawing on our theoretical framework, in the Ukrainian case, means-ends decoupling was sustained at the state level, as the policies and practices of the state were disconnected from its core goal of creating public welfare. It resulted in inconsistencies within the institutional logic of the state, leading to a high degree of institutional complexity experienced by organisations and individuals that did not belong to the privileged group of socalled "rent seekers".

At the beginning of the 1990s, the domestic industry continued to produce hightech products, but this did not last for long (Yurevich 1996). During the transition to a market economy following independence, the domestic economy moved towards "a low equilibrium of high entry barriers for non-insiders, limited incentives for technology adoption, and high concentration on base commodities" (World Economic Forum 2014: 11). As a consequence, the Ukrainian economy became low-tech, based on raw-materials; $80 \%$ of all exports comprised of semi-finished products (World Economic Forum 2014). The reorientation of the Ukrainian economy towards hi-tech imports and low-tech exports hampered the endogenous development of science and innovation (Yegorov and Ranga 2014; Yegorov 2015). Small and medium-sized firms play an important role in innovation and technology adoption (Dettwiler et al. 2006), but the conditions for their development are rather difficult in Ukraine due to the obstacles created by the taxation system and bureaucratisation (World Economic Forum 2014; European Commission 2016). In addition, there is an absence of public policies aimed at supporting start-ups (European Commission 2016). Among the multiple factors that discourage global investors from doing business in Ukraine, corruption, inflation, tax rates, inefficient government bureaucracy and the complexity of tax regulations (World Economic Forum 2015) are important examples.

In the 2000s, venture funds were established, but instead of investing in innovation, they were directed into supporting real estate development. Nowadays, regional innovation research is absent since there is no specific innovation governance system at the regional level (European Commission 2016). Public funding to support research and innovation on a competitive basis represents less than $1.5 \%$ of the state's budget for research (Yegorov and Ranga 2014). The only beneficial factor for the development of innovation during the 2000s became the establishment of information technology (IT) outsourcing companies due to the tendency of diversification among Western IT companies. As for American IT companies, the difference in nine hours between time zones allows outsourcing through Ukraine so as to ensure a 24-hour work cycle. Another important factor in the development of IT in Ukraine was the extensive availability of talented IT youths, the result of strong domestic traditions in engineering education. Despite the willingness of Western IT companies to outsource in such Eastern European countries as Romania and Hungary, both members of the EU, these countries lack skilled IT programmers.

As regards the organisational field of higher education and science in independent Ukraine, its dominant institutional logics are determined by the institutional logic of the state with its contradictory prescriptions. After 1991, higher 
education institutions were expected to do research next to teaching, however, the lack of the knowledge economy in the country and the urge of state actors to preserve much of the Soviet legacy created structural barriers to the development of vibrant domestic science system (Gomilko et al. 2016). Given the fact that Ukraine inherited from the Soviet period the division between higher education institutions and research institutes of the academy of sciences without teaching obligations, the bulk of research funds were allocated to the latter (Osipian 2013; Hladchenko 2016). Furthermore, the strong position of the rectors enables them to convert the higher education institutions into rent-seeking agents geared towards personal gains in terms of prestige, money and positions of power (Stadnyi 2013; Yehorchenko 2014), thus undermining quality of higher education.

\section{Diffusion and Implementation of the Triple Helix in Ukraine}

This section of the paper is divided into two distinct parts. In the first part, we present data insights referring to dynamics (institutional logics) at the societal or macro level, whereas in the second sub-section the focus is on the meso dynamics at the level of the case universities and their respective organisational arrangements for promoting technology transfers (science parks).

\section{Dominant Institutional Logics at the Societal Field Level: "The Macro Picture”}

The diffusion of the Triple Helix model in the Ukrainian context was initiated by the National Technical University of Ukraine 'Kyiv Polytechnic Institute' (KPI), acting as an institutional entrepreneur. In the period 2004-06, KPI participated in the EU's TEMPUS project, titled 'Bridging the Gap between University and Business', together with such European higher education institutions as Delft University of Technology (the Netherlands), the Royal Institute of Technology (Sweden) and the Polytechnic University of Catalonia (Spain). As a result of this collaboration, the first Ukrainian science park (Kyivska Polytechnika) was established in 2006 (Parliament of Ukraine 2006). It was granted the right to conduct entrepreneurial activities and to open bank accounts. Inspired by developments from Europe, KPI's rector voiced the necessity to establish research universities across Ukraine to prepare the country for the knowledge economy (Zgurovskyi 2005). The government supported this initiative and, in 2007, declared its intention to designate five higher education institutions as research universities, promising them additional funding. However, no such policy was adopted until 2009, the year in which presidential elections were scheduled. In 2009, a new legislation allowing universities to establish science parks and conduct entrepreneurial activity was adopted (Cabinet of Ministers of Ukraine 2009). Among the advantages provided to the science parks, the government claimed the import tax exemptions for research equipment and special rental conditions for the partners of the science park. In 2009-2010, in the context of implementation of the Triple Helix model in Ukraine, the government awarded the status of research university to 13 flagship universities, promising them additional state funding for the development of research and 
knowledge transfer capabilities in the following years (Oleksiyenko 2014). The state expectation was that within five years the research universities would earn through knowledge transfer half of what the government allocated to them for research. However, the implementation of the Triple Helix in Ukraine turned into means-ends decoupling at the state level due to the rent-seeking behaviour of the powerful actors from the governmental institutions, e.g., cabinet of ministers. As in the Ukrainian case means-ends decoupling at the state level implied incompatible prescriptions within the institutional logic of the state which caused inconsistencies between the prescriptions imposed by the institutional logics of the market and state, it resulted in institutional complexity for the science parks of the Ukrainian research universities. Firstly, urgent domestic reforms to foster the knowledge economy were not undertaken. Consequently, the institutional logics of the market and of the organisational field of industry were not innovation driven. Thus, there was no demand for research undertaken by the universities. Secondly, the research institutes of the academy of sciences inherited from the Soviet model persisted after the establishment of the research universities. Thus, part of the funding for research was diverted to the former. Thirdly, a new government was appointed in 2010. The latter awarded the status of research university to one additional domestic higher education institution and changed the prior institutional logic of the state by demanding the establishment of science parks at all research universities, irrespective of their disciplinary profiles (Cabinet of Ministers 2010). Moreover, research universities were now required to earn externally half of what the government allocated to them for research in one year instead of five, as initially declared. Research universities did receive additional funding from the state, but it was not sufficient to update their research infrastructures. Further, nothing was said about the allocation of state funding for the establishment of the science parks (Hladchenko et al. 2016). The amount allocated to universities for research decreased annually, thus raising the degree of institutional complexity that they experienced. In 2014, and following the Revolution of Dignity, the new cabinet of ministers abolished the regulation regarding the research universities. In the same year, Russian intervention in the eastern part of Ukraine caused the Ukrainian economy to lose its growing momentum. Moreover, a significant part of the state budget was allocated for defence spending (Oleksiyenko 2016). Regarding the degree of means-ends decoupling at the state level after 2014, it was decreased but not eliminated as governmental institutions remained a source of rent-seeking for the powerful actors heading them (Härtel and Umland 2016).

In the next section, we illuminate how the implementation of the Triple Helix model at each of the case universities manifested itself.

\section{Technical University}

Technical University was founded in 1898 and houses approximately 25,000 students. This university can be considered a flagship among Ukrainian technical universities. In 2011, the university made a breakthrough, becoming the first Ukrainian university to get into QS World University Ranking, though at position $601+$. 
Its science park was established in 2006, following the university's participation in the TEMPUS project. The park started working in $R \& D$, and its director contacted Ukrainian technical companies located in the region in an effort to explore what innovations and solutions they required. In this way, the science park aimed to connect regional industry representatives with local academics. Thus, academics affiliated with the university could direct their research to areas that were of potential interest to industry. The science park managed to establish collaborations with some regional companies, but this was less than expected. Some R\&D projects were undertaken together with larger international companies like Samsung. However, viewing R\&D as just the 'selling of time', the director of the science park strived for the establishment of start-ups.

In 2012, an annual competition ("Sikorsky Challenge") for local start-ups was conducted on the premises of the science park. The three winners were awarded seed funds to establish firms and for further development. The managers of the science park found investors who were interested in supporting these start-ups, and it was expected that students rather than academics would develop the start-up projects. Meanwhile, in the first year of the Sikorsky Challenge, the start-ups did not manage to garner any major investment. According to the director of the science park:

The investors complained that students who represented their projects told them nothing about the advantages of the innovation in general but described in detail the components of the innovation; thus, they presented the projects in a very complicated way. The problem was to teach the students who developed the ideas for start-ups to present the projects in a more 'appropriate' way from the point of view of investors. The investors were not ready to invest money without seeing a ready product or at least a prototype. Taking into account all these shortcomings, we established the start-up school to help the students turn ideas into products (Director, Science Park).

The establishment of the start-up school allowed the Sikorsky Challenge to significantly increase investments in start-ups in the following years. In addition to the collaboration through the science park, the university, in particular the academics from the IT faculty, collaborate with outsourcing IT companies. These companies equip science and education laboratories, and academics using this equipment educate professionals for them. Thus, students and academics have an opportunity to study and conduct research using modern high-tech equipment, while IT companies scoop up employees with the skills and knowledge that they view as important. It is necessary to stress that academics, particularly those from the IT faculty, are quite willing to participate in the science park projects and would like the number of these projects to increase. Moreover, taking into account the Russian intervention in the eastern part of Ukraine, the science park is involved with R\&D in the defence area. Meanwhile, the director of the science park maintains that, nowadays, taking into account the instability of the Ukrainian banking system and economy, there are sufficient investors but not a sufficient number of interesting projects that can be competitive at the international level. Moreover, despite the fact that the university provides a double salary to all academics compared with the state 
appropriation, it is nonetheless uncompetitive with the salary offered by outsourcing IT companies. Thus, employment at the university does not attract the talented graduates in IT.

To summarise, the disciplinary profile of the technical university decreases the degree of the institutional complexity experienced by this science park. However, as the institutional complexity is not eliminated fully, the science park sustains meansends decoupling at the organisational level even despite the senior managers' orientation on practices prescribed by the Triple Helix Model. The means-ends decoupling at the organisational level implies unintended rent-seeking behaviour of the senior managers of the university and the science park. In particular, due to the lack of state funding the science park is neither able to ensure a full-size research infrastructure nor secure the number of projects that academics expect, thus making them look by themselves for the projects that can be conducted at the science park.

\section{Classical University}

This university was established in 1834 and has always been a leading classical Ukrainian university. The university employs approximately 2,900 academics and hosts 26,500 students. In 2014-2015, the university gained position 420 in the QS ranking. The largest share of state funding among domestic higher education institutions, and prestige of the university have contributed to attracting the most talented academics and students from the country. Research has always been a distinctive feature of the university because from the 1950s a research department has functioned in which the academics-primarily from the natural sciences-are appointed to do research. However, almost all of them are employed additionally to teach. This university has the highest position among Ukrainian universities regarding SCOPUS publications. In 2011, the university, together with another higher education institution and three research institutes of the academy of sciences, established a science park. They expected the research institutes to involve them in their projects. In 2012, the science park started to bring in income through research expertise and training courses provided by academics, but not through the creation of innovations together with business and industry as initially planned. The director of the science park highlights that the key hurdle for knowledge transfer with industry is the lack of state interest and support in creating the adequate conditions:

The legislation declared that the state would award innovative projects to the science park, but that did not happen. We regularly write proposals about different innovative projects to the Ministry of Education, but they explain that they do not have funding. The representatives of the governmental institutions claim that their aim is simply to create the legislative basis for the science park so that it could be established and that it is up to the science park to search for projects and establish collaborations with industry. In 2016 alone, the science park got involved in one of the projects of Horizon 2020, which can be viewed as a project that is really connected with innovation (Director, Science Park). 
Thus, for the government, the adoption of the law that allows the establishment of the science park is a sufficient condition for knowledge transfer to occur. Moreover, the interviewee notes that the establishment of the science park requires the creation of the necessary infrastructure; however, according to Ukrainian legislation, it is forbidden for the university to spend its income from tuition fees on the infrastructure of the science park. Thus, it is a vicious circle: in order for the science park to acquire infrastructure, it should generate funds, yet the science park requires a research infrastructure and staff before it can generate any income. Concerning the collaboration with the industry representatives in the region, the director of the science park meets them regularly to present the research of the university's academics. He stresses that it is rather difficult to establish collaboration between representatives of industry and academics because this would require the science park to have the staff with the corresponding skills, which it cannot afford. The director of the science park emphasises that those academics who are well known and have experience in collaboration with industry prefer to provide consultancy to the industry directly instead of doing it via the science park and earning money not only for themselves but also for the university. In most cases, the science park gets a project only if the company ordering a service wants to work with the organisation and not with an individual academic. In 2015 start-up school was established in the university to stimulate entrepreneurial activity among students and academics. Its aim is to provide theoretical knowledge about the basics of innovation enterprise. The science park's director believes that the park requires promotion among academics and students and thus arranges meetings with students and academics, informing them about the opportunities that the science park offers. However, he argues that should there be no change in the behaviour of the state authorities and industry, science parks in Ukraine have no future.

To summarise, as the profile of the classical university with fundamental disciplines is inconsistent with the state's prescriptions to earn significant amounts of money from applied activities, the science park established at this university experiences a higher degree of institutional complexity than the science park at the Technical University. Moreover, despite the science park being unable to provide necessary conditions, the director is confident that academics are obliged to undertake their projects with business via the science park rather than directly as in the past. However, such interpretation of the science park deviates from the global Triple Helix model. Thus, this science park sustains a higher degree of rent-seeking and means-ends decoupling at the organisational level when compared to the science park at the Technical University.

\section{University of Economics}

This university was established in 1906 and nowadays hosts approximately 15,000 students. Its science park was set up in 2011 in order to fulfil the requirements for the status of research university. However, the university did not invest in the establishment of the science park by recruiting all the required staff and creating the necessary infrastructure. The majority of the science park's income emanates from its participation in NATO projects aimed at the retraining of Ukrainian ex-military 
men in an effort to update their qualification by attending courses in marketing management. Meanwhile, similar to the situation with the science park at the Classical University, such a way of earning reflects a case of means-ends decoupling as external income has become a goal in itself irrespective of how it is generated. The director of the science park notes the following barriers to generate income:

Academics are interested in collaboration with the science park if they have a project that requires the payment to be transferred to the organisation and not to the individual. In addition, the science park helps academics to fill out the documents necessary for participation in that or another project. As regards Ukrainian business, it is not interested in investing in innovation; they want to buy a ready-made product. We are working on a software for banks, and we have already presented it at conferences in Ukraine and abroad. Representatives of the banks declare their interest in buying this software when it is ready but do not want to invest money in its development. Regarding the advantages of the science park, while presenting that or another project on behalf of the science park, the name of the university works as a brand (Director, Science Park).

The interviewee points out that according to the Ukrainian legislation, it is expected that the funding for the science park projects is provided by the science park itself, its partners or from the state budget. However, this is the same for other universities; this science park does not have sufficient income to fund its own projects. The manager also highlights that, in reality, the Ukrainian legislation does not give an advantage to businesses that collaborate with science parks. By contrast, those companies investing in science parks are burdened with bureaucratic procedures that involve preparation of different reports for the state authorities. The rent that companies should pay to the university (not to the science park) is the same as in other organisations. The problem is also to get state funding for any project because of the ambiguity of the legislation and the bureaucratic application procedure. According to the science park's director, the adoption of the legislation regarding tax exemption for the company, while it collaborates with the science park on a joint project, could contribute to the development of knowledge transfer between universities and industry. Moreover, the interviewee maintains that it makes more sense to collaborate, not with academics, but with talented students who they enrol as doctoral students, involving them in knowledge transfer projects and providing them with an opportunity to earn extra income. Similarly to the previous two cases, the institutional complexity constrains the director of this science park and triggers means-ends decoupling at the organisational level.

\section{University of Life Sciences}

University of Life Sciences was established as an independent institution in 1923. It currently has around 15,000 students while the total number of academics stands at 1,400. According to the aforementioned legislation, it was expected that the science park would commence operation during 2010 when the status of research university was awarded. There were several unsuccessful attempts at establishing the science 
park. In 2014, a new rector was appointed, and in 2015 the science park was finally established. The director of the science park also takes on the position of department head, and alongside him, there are two academics recruited as staff. The problems experienced by this science park are similar to those facing other universities:

The science park lacks funding for infrastructure and staff recruitment. All the projects that the science park conducts were arranged through my [Director's] personal contacts. In my opinion, there is no systematic approach at the level of the state for the establishment of the activities of the science parks in Ukraine. In particular, the science park cannot even apply for projects that are financed by the education ministry and for which the university can apply. The problem is also the immaturity of the law on intellectual property rights .... Our goal is to attract business representatives by providing them with the material resources and infrastructure of the university. We want to involve them in the processing of the agricultural products. In addition, the university has land that can be used for research in agriculture. We are discussing the possibility of collaboration with one company that works in the area of seeds imports. We can provide it with farm land for the purpose of conducting joint research. The aim of collaboration with business is to establish research and industrial production (Director, Science Park).

The director of the science park analysed the results of the research conducted by local academics and the corresponding patents, and arrived at the conclusion that there was a small level of $R \& D$ that could be commercialised. Meanwhile, he complains that researchers affiliated with the university collaborate directly with industry and not through the science park. Thus, providing consultancy to business, researchers earn money for themselves and not for the science park. The science park's director considers that academics with clients from business who are interested in their research expertise should bring their clients to the science park and share their income with the science park. However, the science park has not created win-win conditions for the academics to provide research consultancy to the business through the science park.

Having studied the experience of science parks in other Ukrainian universities, the director came to the conclusion that there is a tendency among domestic science parks to seek funding applying to international grants. Thus, he also decided to focus on international projects. However, the problem is that international project applications require staff who are proficient in English and who can be involved in searching and applying for international projects. However, as mentioned above, the science park cannot afford to recruit staff with the necessary skills because of the lack of funding.

Similar to his colleague from the University of Economics, the director of this science park notes that the business representatives can be attracted to the science park through lower taxation of the amount they invest in the science park. In his opinion, however, the science park is not only a place for the development and commercialisation of research results but also a place for educating students: 
The problem is that there is no understanding among Ukrainian business representatives that by investing in $R \& D$ they can train future employees. This is so because the labour market in Ukraine is underdeveloped (Director, Science Park).

Further, the interviewee points to the fact that neither academics nor business representatives are aware of the advantages of the science park and that, with time, marketisation will become a reality. Although this science park experiences the same level of institutional complexity as the science parks at the Classic University and the University of Economics, it sustains a higher degree of means-ends decoupling due to the higher degree of rent-seeking behaviour of the senior managers of the university and the science park. The science park lacks the necessary infrastructure and does not provide academics with favourable conditions for earning externally, yet the senior managers expect academics to bring in external income. High degree of the rent-seeking behaviour of the managers of the university and the science park occurs because they are guided by a logic of confidence in old (institutionalised) practices that deviate from the Triple Helix model.

\section{Discussion and Conclusion}

The data presented above show that means-ends decoupling at the state level, caused by the rent-seeking behaviour of business and political oligarchies, led to the implementation of the Triple Helix model in Ukraine also reflecting a case of means-ends decoupling. Consequently, contradictions within the institutional logic of the state resulted in a high degree of institutional complexity experienced by the science parks established at the case universities. In terms of the Triple Helix, the Ukrainian government implemented a static rather than an overlapping model (Etzkowitz 2002; see Fig. 1 above). This occurred because the institutional logic of the state is, to a large extent, determined by the rent-seeking behaviour of business and political oligarchies. As such, the state is not driven by the economic and societal interests of the citizens/public but, rather, those of a few dominant rent seekers or profiteers. In order for the government to be able and willing to implement the global models of the world society, including the Triple Helix, without deviance, changes in the dominant institutional framework or societal order (associated with the identified institutional logics) would be required (Thornton et al. 2012). For this to happen, however, it would imply proper mechanisms to enhance state accountability, the development of market institutions, and a vibrant civil society. Moreover, the state should shift its focus from rent-seeking to its core goal of creating public welfare. In the Ukrainian case, instead of empowering both organisational and individual actors, current domestic institutional arrangementsregulative, normative and cultural-cognitive (Scott 2014) — constrain them, not allowing them to function as purposive and agentic actors as prescribed by the global models of world society (Meyer 2010), including the Triple Helix. This occurs because the means and ends of individual and organisational actors are embedded within the prevailing institutional logics (Thornton and Ocasio 2008). 
What is more, means-ends decoupling at the state level causes the means and ends of the organisational actors to be also decoupled due to the institutional complexity that they confront. That is, institutional complexity triggers means-ends decoupling at the organisational level, as claimed by Bromley and Powell (2012). Due to the institutional complexity, the senior managers of the universities and science parks unable to create win-win conditions for academics to earn additional income through the science park, demand that academics earn for the university. This is similar to a chain reaction: the state, despite being unable to create win-win conditions for universities to earn externally, demands that they earn through knowledge transfer, and the managers of universities behave in a similar manner. This, in turn, suggests that in a weakly institutionalised environment characterised by financial scarcity and little oversight (accountability), resource dependencies can have a detrimental effect on goal achievement (Pfeffer and Salancik 2003). However, the Ukrainian situation also attests to the resilience of newly formed organisational arrangements in their ability to generate additional income in the absence of a supportive regulative framework (Hardy and Maguire 2008; Pinheiro 2016). In this respect, one possible interpretation of the role of the state insofar as the Triple Helix is concerned could be that the focus was less on promoting collaboration (transfer of knowledge) between industry and academia and more about injecting a "spirit of enterprise" or entrepreneurialism within the internal fabric of public universities (Slaughter and Leslie 1997; Pinheiro and Stensaker 2014).

As regards the degree of institutional complexity experienced by the science parks, it depends not only on the financial resources of the science park but also on the degree of consistency between the institutional environment and the particularities of the disciplinary profile of the university. Thus, the science park of Technical University experiences a less degree of institutional complexity compared to the science parks of three other case universities. The greater institutional complexity experienced by the science park implies the larger mean-ends decoupling and rent-seeking at the organisational level. In addition, the more senior managers of the university and the science park maintain the logic of confidence in practices that deviate from the Triple Helix model, the greater rentseeking and means-ends decoupling at the organisational level, e.g., the University of Life Sciences.

One of the many negative consequences of means-ends decoupling at the state level and rent-seeking behaviour of powerful actors in governmental institutions is the loss of intellectual capital through brain drain (Kupych 2016). In the absence of a supportive institutional environment and resource conditions, talented graduate and postgraduate students as well as entrepreneurial and engaged academics, are likely to look elsewhere for opportunities. The same refers to means-ends decoupling at the organisational level and rent-seeking behaviour of the universities' senior managers.

Meanwhile, our empirical findings from the case of the University of Economics resonate with Thune (2010) and Pinheiro, Normann and Johnsen (2016), suggesting that the university-industry-government interaction could create a beneficial environment for the research training of doctoral students. Another challenge 
pertains to matching supply and demand (strategic response) in an environment laden with multiple and often contradictory demands imposed by institutional logics (Greenwood et al. 2011; Thornton et al. 2012). As indicated by the director of one of the science parks, despite a large number of patents by the local university, it was nonetheless difficult to find academic projects of interest to local industry. This is also the result of the means-ends decoupling at the state level; the longer that such a condition is preserved, the more intellectual capital the country is likely to lose.

Thus, the longer means-ends decoupling and rent-seeking will persist both at the state and organisational levels, the further will Ukraine move away from the socalled 'world society' and its corresponding institutional arrangements (Lechner 2009). Interestingly, such issues have come to the fore during an unprecedented historical moment in which such liberal-minded institutional arrangements (markets, rules, knowledge, etc.) are being contested, in Europe and elsewhere (Howden 2011; Jacobs and Mazzucato 2016).

Going forward, the state should provide attractive conditions, both in terms of incentives and a coherent regulative framework, for universities to be actively involved with knowledge transfers in partnership with industry. Likewise, the universities should provide academics with beneficial conditions (win-win situations) for them to collaborate with industrial partners through the science parks, thus minimising the risk of being perceived as local competitors. Future studies could, for example, focus on the interplay between path- and resource-dependencies as well as strategic agency in processes relating to the implementation and institutionalisation of the Triple Helix at different points in time, and within the scope of university systems with distinct disciplinary profiles and local traditions.

\section{Compliance with Ethical Standards}

Conflict of interest The authors declare that they have no conflict of interest.

Open Access This article is distributed under the terms of the Creative Commons Attribution 4.0 International License (http://creativecommons.org/licenses/by/4.0/), which permits unrestricted use, distribution, and reproduction in any medium, provided you give appropriate credit to the original author(s) and the source, provide a link to the Creative Commons license, and indicate if changes were made.

\section{References}

Åslund, Anders. 2000. Why has Ukraine failed to achieve the economic growth? In Economic Reform in Ukraine: The Unfinished Agenda, eds. Anders Åslund, and Georges de Ménil, 255-279. New York: M.E. Sharpe.

Åslund, Anders. 2001. Ukraine's return to economic growth. Post-Soviet Geography and Economics 42(5): 313-328.

Benneworth, Paul, Harry de Boer, and Ben Jongbloed. 2015. Between good intentions and urgent stakeholder pressures: Institutionalizing the universities' third mission in the Swedish context. European Journal of Higher Education 5(3): 280-296.

Berg, Laila, and Rómulo Pinheiro. 2016. Handling different institutional logics in the public sector: Comparing management in Norwegian universities and hospitals. In Towards a comparative 
institutionalism: Forms, dynamics and logics across health care and higher education fields, eds. Romulo Pinheiro, Lars Geschwind, Francisco Ramirez, and Karsten Vrabæk, 145-168. Emerald: Bingley.

Bromley, Patricia, and Walter Powell. 2012. From smoke and mirrors to walking the talk: Decoupling in the contemporary world. The Academy of Management Annals 6(1): 483-530.

Cai, Yuzhuo. 2014. Implementing the Triple Helix model in a non-Western context: An institutional logics perspective. Triple Helix 4(1): 1-20.

Caldera, Aida, and Olivier Debande. 2010. Performance of Spanish universities in technology transfer: An empirical analysis. Research Policy 39(9): 1160-1173.

Dettwiler, Paul, Peter Lindelöf, and Hans Löfsten. 2006. Utility of location: A comparative survey between small new technology-based firms located on and off science parks - Implications for facilities management. Technovation 26(4): 506-517.

Dick, Penny. 2015. From rational myth to self-fulfilling prophecy? Understanding the persistence of means-ends decoupling as a consequence of the latent functions of policy enactment. Organization Studies 36(7): 897-924.

Egorov, Ihor. 1996. Trends in transforming R\&D potential in Russia and Ukraine in the early 1990s. Science and Public Policy 23(4): 202-214.

Etzkowitz, Henry, and Loet Leydesdorff. 1998. The endless transition: A Triple Helix of universityindustry-government relations. Introduction. Minerva 36(3): 203-208.

Etzkowitz, Henry, and Loet Leydesdorff. 2000. The dynamics of innovation: From national systems and "Mode 2" to a Triple Helix of university-industry-government relations. Research Policy 29: 109-123.

Etzkowitz, Henry, Magnus Gulbrandsen, and Janet Levitt. 2001. Public venture capital: Sources of government funding of technology entrepreneurs. New York: Aspen.

Etzkowitz, Henry. 2002. Networks of Innovation: Science, Technology and Development in the Triple Helix Era. International Journal of Technology Management \& Sustainable Development 1(1): 7-20.

Etzkowitz, Henry. 2003. Innovation in innovation: The Triple Helix of university-industry-government relations. Social Science Information 42(3): 293-337.

European Commission. 1997. Towards a Europe of knowledge. Brussels.

European Commission. 2016. Peer review of the Ukrainian research and innovation. Horizon 2020 policy support facility. https://rio.jrc.ec.europa.eu/sites/default/files/report/KI\%20AX\%2016\%20008\% 20EN\%20N_UKR_0.pdf. Accessed 12 February 2017.

Geuna, Aldo, and Alessandro Muscio. 2009. The governance of university knowledge transfer: A critical review of the literature. Minerva 47(1): 93-114.

Gioia, Dennis A., Shubha D. Patvardhan, Aimee L. Hamilton, and Kevin G. Corley. 2013. Organisational identity formation and change. The Academy of Management Annals 7(1): 123-193.

Gomilko, Olga, Denys Svyrydenko, and Sergii Terepyschyi. 2016. Hybridity in the higher education of Ukraine: Global logic or local idiosyncrasy? Philosophy and Cosmology 17: 177-1999.

Greenwood, Royston, Mia Raynard, Farah Kodeih, Evelyn R. Micelotta, and Michael Lounsbury. 2011. Institutional complexity and organizational responses. The Academy of Management Annals 5(1): 317-371. https://doi.org/10.1080/19416520.2011.590299.

Grodal, Stine, and Siobhan O'Mahony. 2015. From field consensus to fragmentation: How means-ends decoupling hinders progress on grand challenges http://people.bu.edu/grodal/grand_challenge.pdf. Accessed 4 January 2017.

Guriev, S., and K. Sonin. 2009. Dictators and oligarchs: A dynamic theory of contexted property rights. Journal of Public Economics 93(1): 1-13.

Hall, Peter, and Rosemary Taylor. 1996. Political science and the three new institutionalisms. Political Studies 44(5): 936-957.

Hardy, Cynthia, and Steve Maguire. 2008. Institutional entrepreneurship. In The SAGE Handbook of Organizational Institutionalism, eds. Royston Greenwood, Christine Oliver, Roy Suddaby, and Kerstin Sahlin-Andersson, 198-217. London: Sage Publishers.

Härtel, Andre, and Andreas Umland. 2016. Challenges and implications of Ukraine's current transformation. https://papers.ssrn.com/sol3/papers.cfm?abstract_id=2776536 Accessed 15 May 2017.

Hellman, Joel. 1998. Winners take all: The politics of partial reform in postcommunist transition. World Politics 50(2): 203-234. 
Hladchenko, Myroslava, Don Westerheijden, and Harry de Boer. 2018. Means-ends decoupling at the state level and managerial responses to multiple organisational identities in Ukrainian research universities. Higher Education Research \& Development, 1-14.

Hladchenko, Myroslava, and Don Westerheijden. 2018. Means-ends decoupling and academic identities in Ukrainian university after the Revolution of Dignity. European Journal of Higher Education 8(2): 152-168.

Hladchenko, Myroslava, Harry de Boer, and Don Westerheijden. 2016. Establishing research universities in Ukrainian higher education: The incomplete journey of a structural reform. Journal of Higher Education Policy and Management 38(2): 111-125.

Hladchenko, Myroslava. 2016. The organizational identity of Ukrainian universities as claimed through their mission statements. Tertiary Education and Management 20(4): 376-389.

Howden, David. 2011. Institutions in crisis: European perspectives on the recession. Gloucestershire: Edward Edgar Publishing.

Jacobs, Michael, and Mariana Mazzucato. 2016. Rethinking capitalism: Economics and policy for sustainable and inclusive growth. Chichester: Wiley-Blackwell.

Koning, Edward. 2016. The three institutionalisms and institutional dynamics: Understanding endogenous and exogenous change. Journal of Public Policy 36(4): 639-664.

Krueger, Anne. 1974. The political economy of the rent-seeking society. The American Economic Review 64(3): 291-303.

Kupych, Bohdan. 2016. Ukrainian IT industry: How to transform Ukraine's brain drain into brain gain. http://global-ukraine-news.org/ru/2016/08/20/ukrainian-industry-transform-ukraine-s-brain-drainbrain-gain/\#prettyPhoto. Accessed 12 January 2017.

Lach, Saul, and Mark Schankerman. 2008. Incentives and inventions in universities. The RAND Journal of Economics 39(2): 403-433.

Löfsten, Hans, and Peter Lindelöf. 2002. Science parks and growth of new technology-based firmsAcademic-industry links, innovation and markets. Research Policy 31: 859-876.

Lechner, Frank. 2009. Globalization: The making of world society. Chichester: John Wiley \& Sons.

Lester, Richard, and Markku Sotarauta (eds.). 2007. Innovation, universities and the competitiveness of regions. Helsinki: Tekes.

Mahoney, James, and Kathleen Thelen. 2010. A theory of gradual institutional change. Ambiguity, agency and power. In Explaining institutional change, eds. James Mahoney and Kathleen Thelen, 1-37. Cambridge: Cambridge University Press.

Marcovich, Anne, and Terry Shinn. 2011. From the Triple Helix to a Quadruple Helix? The Case of DipPen Nanolithography. Minerva 49(2): 175-190.

Meyer, John, John Boli, George M. Thomas, and Francisco O. Ramirez. 1997. World society and the nation-state. American Journal of Sociology 103(1): 144-181.

Meyer, John, and Brian Rowan. 1977. Institutionalized organisations: Formal structure as myth and ceremony. American Journal of Sociology 83: 440-463.

Meyer, John, and Ronald L. Jepperson. 2000. The 'actor' of modern society: The cultural construction of social agency. Sociological Theory 8(1): 100-120.

Meyer, John. 2010. World society, institutional theory, and the actor. Annual Review of Sociology 36: $1-20$.

Meyer, Renate, and Markus Höllerer. 2016. Laying a smoke screen: Ambiguity and neutralization as strategic responses to intra-institutional complexity. Strategic Organization 14(4): 373-406.

Mowery, David, and Nathan Rosenberg. 1989. New development in US technology policy: Implications for competitiveness and international trade policy. California Management Review 32(1): 107-124.

Oleksiyenko, Anatoly. 2014. Socio-economic forces and the rise of the world-class research university in the post-Soviet higher education space: The case of Ukraine. European Journal of Higher Education 4(3): 249-265.

Oleksiyenko, Anatoly. 2016. Higher education reforms and center-periphery dilemmas: Ukrainian universities between neo-Soviet and neo-liberal contestations. In Globalisation and higher education reforms, eds. J. Zajda and V. Rust, 133-148. Berlin: Springer.

Osipian, Ararat. 2013. Transforming university governance in Ukraine: Collegiums, bureaucracies, and political institutions. Higher Education Policy 27(1): 65-84.

Parliament of Ukraine. 2006. Law of Ukraine on Science Parks “Kyivska Polytechnika”. http://zakon3. rada.gov.ua/laws/show/523-16. Accessed 23 August 2016.

Parliament of Ukraine. 2009. Law of Ukraine on Science Parks. http://zakon3.rada.gov.ua/laws/show/ 1563-17. Accessed 14 June 2016. 
Pinheiro, Rómulo, Paul Benneworth, and David Jones. 2012. Universities and regional development: A critical assessment of tensions and contradictions. Milton Park and New York: Routledge.

Pinheiro, Rómulo, and Bjorn Stensaker. 2014. Designing the entrepreneurial university: The interpretation of a global idea. Public Organization Review 14(4): 497-516. https://doi.org/10.1007/s11115013-0241-z.

Pinheiro, Rómulo, Patricio Langa, and Attila Pausits. 2015. One and two equals three? The third mission of higher education institutions. European Journal of Higher Education 5(3): 233-249.

Pinheiro, Rómulo. 2016. Humboldt meets Schumpeter? Interpreting the 'entrepreneurial turn' in European higher education. In Competitive advantage: Stratification, privatization and vocationalization of higher education in the US, EU, and Canada, eds. Sheila Slaughter and Barrett J. Taylor, 291-310. Dordrecht: Springer.

Pinheiro, Rómulo, Roger Normann, and Hans C.G. Johnsen. 2016. External engagement and the academic heartland: The case of a regionally-embedded university. Science and Public Policy 43(6): 787-797. https://doi.org/10.1093/scipol/scw020.

Pfeffer, Jeffrey, and Gerald R. Salancik. 2003. The external control of organizations: A resource dependence perspective. Stanford, California: Stanford Business Books.

Powell, Walter, and Jason Owen-Smith. 2002. The new world of knowledge production in the life sciences. In The future of the city of intellect: The changing American university, ed. Steven Brint, 107-130. Stanford, California: Stanford University Press.

Quintas, Paul, David Wield, and Doreen Massey. 1992. Academic-industry links and innovation: Questioning the science park model. Technovation 12(3): 161-175.

Saad, Mohammed, Girma Zawdie, and Chandra Malairaja. 2008. The triple helix strategy for universities in developing countries: The experiences in Malaysia and Algeria. Science and Public Policy 35(6): 431-443.

Scott, W. Richard. 2014. Institutions and organizations: Ideas, interests, and identities. 4th ed. Thousand Oaks: SAGE Publications.

Slaughter, Sheila, and Larry Leslie. 1997. Academic capitalism: Politics, policies and the entrepreneurial university. Baltimore: Johns Hopkins University Press.

Stadnyi, Yegor. 2013. Why Do the Rectors Support the Law of the Deputies from the Party of Regions. http://osvita.ua/vnz/reform/35036/. Accessed 12 February 2017.

Thornton, Patricia, and William Ocasio. 1999. Institutional logics and the historical contingency of power in organisations: Executive succession in the higher education publishing industry, 1958-1990. American Journal of Sociology 105: 801-843.

Thornton, Patricia, and William Ocasio. 2008. Institutional logics. In The SAGE Handbook of Organizational Institutionalism, eds. Royston Greenwood, Christine Oliver, Roy Suddaby, and Kerstin Sahlin-Andersson, 99-128. London, UK: Sage.

Thornton, Patricia, William Ocasio, and Michael Lounsbury. 2012. The institutional logics perspective: A new approach to culture, structure, and process. Oxford: Oxford University Press.

Thune, Taran. 2010. The training of "Triple Helix workers"? Doctoral students in university-industrygovernment collaboration. Minerva 48(4): 463-483.

Tollison, Robert. 1982. Rent seeking: A survey. Kyklos 35(4): 575-602.

Wittkowsky, Andreas. 1999. Der Nationalstaat als Rentenquelle - Determinanten der Ukrainischen Politik. Internationale Politik und Gesellschaft: 150-161.

World Economic Forum. 2014. Scenarios for Ukraine. http://www3.weforum.org/docs/WEF_ ScenariosSeries_Ukraine_Report_2014.pdf Accessed 3 October 2016.

World Economic Forum. 2015. The global competitiveness report 2015-2016. http://www3.weforum.org/ docs/gcr/2015-2016/Global_Competitiveness_Report_2015-2016.pdf. Accessed 3 October 2016.

Yehorchenko, Iryna. 2014. The strategy of reforming of higher education in Ukraine till 2020: comments and suggestions http://education-ua.org/ua/draft-regulations/342-strategiya-reformuvannyavishchoji-osviti-v-ukrajini-do-2020-roku-komentari-ta-propozitsiji. Accessed 2 February 2017.

Yegorov, Igor, and Marina Ranga. 2014. Innovation, politics and tanks: The emergence of a Triple Helix system in Ukraine and the influence of the EU cooperation on its development. International Journal of Transitions and Innovation Systems 3(3): 189-224.

Yegorov, Igor. 2009. Post-Soviet science: Difficulties in the transformation of the R\&D systems in Russia and Ukraine. Research Policy 38(4): 600-609.

Yegorov, Igor. 2015. Innovation policy and implementation of the Triple Helix concept in Ukraine. Optimum Studia Ekonomiczne 5(77): 155-167.

Yin, Robert. 2009. Case study research: Design and methods. London: Sage Publications. 
Yurchenko, Yulia. 2018. Ukraine and the empire of capital. Northampton: Pluto Press, Stanford DTP Service.

Yurevich, Leonid. 1996. Ukraine: Developing innovation policies for a recently independent economy. Science and Public Policy 23(5): 266-277.

Zietsma, Charlene, Peter Groenewegen, Danielle Logue, and Bob Hinings. 2016. Field or fields? Building the scaffolding for cumulation of research on institutional fields. Academy of Management Annals 11(1): 391-450.

Zgurovskyi, Mykhailo. 2005. Ukraine still has a chance. http://gazeta.dt.ua/EDUCATION/ukrayina_ sche_mae_shans.html. Accessed 3 October 2016. 